\title{
INDIRECTNESS IN THE COMMUNICATION OF PROSTITUTES IN SURABAYA
}

\author{
Suswanto Ismadi Megah S
}

megah76@yahoo.co.id

English Language Teaching FKIP UNRIKA Batam

\begin{abstract}
This research aims to identify how the prostitutes communicate to their clients in Surabaya. The data were obtained from the real communication occurring among the prostitutes' and the clients. It was found that Indonesian language is dominantly used in the communication compared to Javanese language. This is due to the fact that Javanese language is more complicated having different speech levels based on the social status of the speakers. Furthermore, the research showed that the prostitutes tend to use euphemism in their service. The euphemism is part of the style of Javanese prostitutes performing indirectness as a part of Javanese culture.
\end{abstract}

Keywords: Communication, Prostitutes, Javanese Prostitutes, Indirectness, Euphemism.

\section{INTRODUCTION}

Communication is one of the tools to fulfil human needs in their life. According to Baskaran (2005, p.1) communication is a wide ranging term which involves various variables as it concerns with the way human transfer messages. Besides, Ismadi (2009, p.1) comments that communication involves two or more people coding and encoding messages to each other through the medium of language.

Language is a crucial tool for human beings to express their desires, moods, feelings, and needs. On a more complex level, language is not just a communication tool but an instrument for social interaction. Just as there are many languages in this world, some are similar in some ways while others are totally different in every way, communication through these languages also requires the use of specific linguistic features and rules to convey meaning effectively. Hence, communication to fulfil the need for social interaction also requires specific linguistic features to be effective.

Moreover, Ismadi (2009,p. 1) asserts that communication is influenced by the background of the speakers, for instance, their culture. In the Javanese culture, for example, indirectness in speech and action is considered more polite than being direct; indirectness therefore is a daily practice. Therefore, it is aimed to preserve a good relationship between the speaker and the hearer. Furthermore, Gunarwan (1997, p.1) states that the Javanese tend to speak more indirectly compared to the speakers of other language, for instance the Bataks. This characterizes the culture to preserve the good relationship through effective communication. It is also in line with the concept of politeness. Geertz (1961) and Suseno (1984) stress the importance of exploring Javanese etiquette as an introduction into the understanding of Javanese politeness. They strengthen the fact that communication and politeness within the context of culture is inseparable.

According to Connelly (1980, p. 68), prostitution is one phenomenon in social life. It grows despite the consequence that it arises conflict in the society because of moral perspective, particularly in religious teaching and health reason. In addition, Ismadi (2009, p. 4) says that in Indonesia, where the main religion is Islam which does not condone prostitution, the profession is thriving to a point that the business of selling and buying of sex is done openly. In other side, Liem 
(1992, p. 37) says that the biggest brothel complex in Asia in terms of the number of active prostitutes is in Surabaya. This can be viewed that in a country where poverty level is rising and jobs are insufficient to support a rapidly growing population, many chose resort to prostitution for survival. This is very contrast with the condition of Surabaya known as religious city but the prostitution is still grown up. This is due to urgently economic needs to survive in the big city such as the capital of East Java, Surabaya. Ismadi (2009, p. 5) adds that competition is strong as every seller is selling the same item and every buyer is looking for quality and best price. Hence, in the competition the communication strategies of the prostitutes play a significant role.

In this research, the prostitution is viewed in term of communication among prostitutes and clients. This research analyzes the language used by the prostitutes. Lyon (1997, p. 175) says that the prostitute's language has the capacity to produce a certain emotional effect upon the hearer. Therefore this study tries to explore the capacity of the language as Fauzi (2000) has noted that a group of Javanese prostitutes in Surakarta used registers and they tended to use specific codes which are understood only by them and the people who use their services to disguise and protect themselves.

It is based the above rationale that this research investigates the communication strategies used by the prostititues during talking with their clients involving the offer of their services. In addition, this research also aimed to analyze the indirectness of communication among prostitutes and clients in Surabaya.

\section{METHOD}

In this research, seven subjects are taken as the research subjects. The subjects could be categorized as lower class prostitutes who offer their service for the price ranging from Rp.50.000,- to Rp.70.000,for one session. According to Koentjoro (2004, p. 65) the rates of the sex services are based on four criteria: length of service, age and physical features (for example skin colour and body shape) of the prostitutes as well as the skills they possess. Therefore the subjects were selected to see the communication strategies employed in competing to get the clients.

In collecting of the data, audio recording was used to capture the naturally occurring conversations in which the subjects were not trained or guided in any sense. They were questioned and the conversation was arranged on how they usually do with their potential clients.

\section{THE LANGUAGE OF PROSTITUTES}

The data of this research show thatsome prostitutes used Javanese language which has several levels of usage based on the social status of the speakers as well as the context of the speech. Within these levels, certain words have several synonyms which are used depending on the context and the relationship between the speakers. In this case, the context of negotiation using the language also influenced by the language choice. The research subjects also did such kind of offer. This was used to attract the clients. Therefore, the clients was obliged to say something or to appropriately respond to the offer. At the initial stage, the hearer may feel happy and/or unhappy with the offer made. Choice of words therefore plays an important role in making the offer effective.

Another word exposed by the subjects when the clients has agreed with thelower price offered is pasarane (standard price in that place). It is a sign that the clients are of the lower socio-economic status maintaining the price control. Observations of the subjects in action revealed that the subjects do indeed confirm or adjust the judgements made during the initial assessments of the clients' social status as they begin to speak to the clients.

Moreover, the prostitutes used communication strategies to offer the service but they avoid stating the terms related to sex directly when negotiating with their potential clients. They used different style of using diction when they negotiated with potential clients depending on the age and social status of the clients based on the age, educational background and experience of the subjects themselves. According they employ euphemisms.

Eventually, in negotiation euphemism is mostly used to preserve privacy of both sides, the subjects and the potential clients. 
Protection of face for Javanese people is taken seriously to avoid isin (feel ashamed), and perkewoh (sense of humility or humbleness) in case the negotiation of sex is known to other people.As a consequence, the dignity of the subjects should be maintained.

\section{Indirectness as Javanese Communication Style}

Javanese people have a style in communication, namely indirectness, becausethey have high consideration to say directly to the hearers. Therefore, indirectness is commonly used as one the Javanese politeness features in communication among Javanese people. It is in line with Geerzt (1961, p. 208) and Suseno (1984, p. 44) who state that a polite Javanese generally speaks indirectly. Similarly, Gunarwan (1997, p. 1) stated that the Javanese tend to speak more indirectly compared to the Bataks who tend to speak more directly. The Bataks who live in North Sumatra tend to speak strongly and directly. It is in contrast with the Javanese culture, that the indirectness shows politeness conveyed in conversation.

Furthermore, Gunarwan (2003, p. 217) adds that Javanese is well-known for speaking indirectly; this is especially aimed to save face of both the speaker and the hearer. Yuliana (2003) also emphasizes that the Javanese living Probolinggotend to speak more indirectlycompared to the people from Madura ethnic in East Java Province. Thus, the Javanese culture basically shows that indirectness is common when stating their wants. Suseno and Geertz (1961) both agree that there are two principles which motivate Javanese people to avoid being direct. Those principles are rukun (harmony) and hormat (respect).

In this research, the indirectness is shown through euphemism. The euphemism is as the lexical choice in offering the sex service which is most appropriate strategy to use in order to attract the potential client's attention and to protect both faces as well. Protection of face for Javanese people is taken seriously to avoid feeling ashamed and support the sense of humility or humbleness in sex negotiation. It is illustrated as follows:

\section{Subject 1 Translation}

(5) S1: Istirahat Have a rest here /
keNE / [smile] [smile]

Subject 2

(3) S2: [smile] Pijet- [smile] just massage, pijetan $\mathrm{THO}$ ?

Subject 3

(1) S3: Mas pijetan Sir, get massage mas....?[smile]

Subject 4

(5) S4: Pak ayo Sir let's take a istirahat...[smile]. $\quad$ rest......[smile]

Subject 5

(3) S5: Mau istirahat Will \{you take a rest / /apa minum dulu? what about drinking first?

\section{Subject 6}

(3) S6: Mau minum Will \{you\} drink or atau istirahat?

Subject 7

(3) S7: $\mathrm{Pa}$ mas servisnya seperti nDoli?

\section{Subject 8}

(3) S24: Mau minum apa mau nyewek?

\{What\} do\{you $\}$ want, to have a drink or make love?

The data provided evidence that the more commonly used word for 'having sex' is 'istirahat' which is translated into English as 'take a rest' or 'relaxation'. Wanting to be very polite, by using istirahat, the subjects above have placed themselves in a much lower position than their potential clients. From the interview they have all explained that they did so because their livelihoods depend on securing a deal with the potential clients. As the 'seller', they must do all they can especially at the negotiation stage, to persuade the clients to like them and hence hire them. To them the customer is 'a king' and must therefore be spoken to with utmost respect.

S2 and S3 used pijet-pijetan in place of the more polite istirahat mainly because at this point all they want to get across to the potential clients is whether they wanted their services or not. Therefore at this stage the main strategy is the use of direct question forms. Once the potential client indicates interest, the negotiation will move into getting an agreement on the price. Pijetpijetan translates as a massage, however, used in this context, as an offer of more than just a massage but also sex. As most initial 
offers made by the subjects in the study, both S2 and S3accompany their utterances with a smile, which in itself is a show of respect and friendliness.

In the data, S7 used the English word servis (service) as a euphemism for sex which is also a strategy to mitigate her offer. This is regarded as more polite than using the Indonesian equivalent melayani (to serve). So, if S7 had used melayani she will be risking hers as well as the client's face because ngalayani (Javanese word) has the connotation of service provided by a servant (lower class) to the employer (upper class). In addition, S7 also gives respect to the client because English in Indonesia is associated with highly educated speakers. With S7 in particular, she is talking to is a younger client who looks educated and she perceived that he would be pleased if she uses English with him (as revealed by S7 during the interview with her). Furthermore, based on her perception of him, she also made reference to the $n$ Dolly (name of high class brothel) type of service. The suggestion made here on the part of S7 to the potential client is that she sees him as a person who would want more than just the usual services provided in this area. In addition she is the one who can actually provide him with the type of services he deserves as she knows the quality of service provided at Dolly brothels.

\section{CONCLUSION}

This research concluded that the prostitutes tend to use euphemism in their service. The euphemism is part of the style Javanese prostitutes that indirectness is part of Javanese culture.Euphemism used in negotiation refers to indirectness to preserve the 'face' of both sides (the subjects and the clients). Therefore, the present study is based on the notion that communication is culturebound; that members of a particular culture particularly Javanese culture.

In addition, this research also found that despite the prostitutes are mostly Javanese, the use of Indonesian language is more dominant in their communication. It is based on the fact that Indonesian language is an alternative in choosing the appopriate words for the negotiation. In addition, among Javanese speaker they tend to avoid misuse of the language speech levels and the inability of the speakers to use right Javanese stylistic level, which is especially used by young subjects.

\section{REFERENCES}

Baskaran, Loga. (2005). Linguistics Primer. Kuala Lumpur: University of Malaya Press.

Connelly, Mark Thomas. (1980). The Response to Prostitution in The Progressive Era, America: The University of North Carolina Press.

Geertz, Clifford. (1960). The Religion of Java. Glencoe, IL Free Press.

Geertz, Hilder. (1961). The Javanese Kindship Family. Glencoe, IL Free Press. Excerpted in Fishman (1968a) and Pride and Holmes (1972).

Gunarwan, Asim. (1997). "Persepsi kesantunan direktif di dalam bahasa Indonesia di antara beberapa kelompok etnik di Jakarta". In Kaswanti Purwo (Ed.). PELLBA.

Fauzi,Ichsanto. (2000). A Descriptive Analysis of Register used by Prostitutes in Surakarta. Unpublished Thesis: UMS

Ismadi, Suswanto. (2009). Mampir Mas: Politeness Strategies of Offers among Javanese Sellers. Unpublished Master Thesis: UM.

Koentjoro. (2004). On the Spot: Tutur dari Sarang Pelacur.Tinta: Yogyakarta. 
Koentjoroningrat. (1985). Javanese Culture. Oxford University Press. Sinapore.

Liem, Lien Leam. (1992). The Sex Sector, The Economic and Social Bases of Prostitution in Southeast Asia. Geneva: International Labour Office.

Lyons, John. (1997). Semantics. Volume I. Cambridge: Cambridge University Press.

Suseno, Franz Magnis. (1984). Etika Jawa. Jakarta: P.T. Gramedia. 